\title{
Corrigendum: Emerging Roles of Strigolactones in Plant Responses to Stress and Development
}

\author{
Amita Pandey *, Manisha Sharma and Girdhar K. Pandey \\ Department of Plant Molecular Biology, University of Delhi, New Delhi, India
}

Keywords: plant hormones, strigolactones, abiotic stresses, biotic stresses

\section{A corrigendum on}

Emerging Roles of Strigolactones in Plant Responses to Stress and Development by Pandey, A., Sharma, M., and Pandey, G. K. (2016). Front. Plant Sci. 7:434. doi: 10.3389/fpls.2016.00434

In the original article, Section "Strigolactones and Plant Growth and Development," Sub-section "Senescene," Liu et al. (2013) should have been cited instead of Czarnecki et al. (2013).

Similarly, in the section "Strigolactone Biosynthesis," Sub-section "Carotenoids," last paragraph, the reference Schwartz et al. (1997) should be considered instead of Schwartz et al. (2004).

In addition, in the Section "Regulatory Mechanisms of Strigolactone Signaling," Sub-section

OPEN ACCESS

Edited and reviewed by: Rajeev K. Varshney, International Crops Research Institute for the Semi-Arid Tropics, India

*Correspondence: Amita Pandey amitap04@gmail.com

Specialty section: This article was submitted to Plant Genetics and Genomics,

a section of the journal Frontiers in Plant Science

Received: 06 May 2016 Accepted: 31 May 2016

Published: 24 June 2016

Citation: Pandey A, Sharma M and Pandey GK (2016) Corrigendum: Emerging Roles of Strigolactones in Plant Responses to Stress and Development.

Front. Plant Sci. 7:860. doi: 10.3389/fpls.2016.00860
"Transcription," second paragraph, the reference Nakamura et al. (2013) should not be considered for this publication.

The authors apologize for these errors. These changes do not affect the scientific conclusions of the article.

\section{AUTHOR CONTRIBUTIONS}

AP has contributed to the writing of this MS. MS has contributed to reading and editing of the MS. GP has contributed to the critical reading and editing of the MS.

\section{REFERENCES}

Liu, J., Novero, M., Charnikhova, T., Ferrandino, A., Schubert, A., Ruyter-Spira, C., et al. (2013). CAROTENOID CLEAVAGE DIOXYGENASE 7 modulates plant growth, reproduction, senescence, and determinate nodulation in the model legume Lotus japonicus. J. Exp. Bot. 64, 1967-1981. doi: 10.1093/jxb/e rt056

Schwartz, S. H., Tan, B. C., Gage, D. A., Zeevaart, J. A. D., and McCarty, D. R. (1997). Specific oxidation cleavage of carotenoids of VP14 of maize. Science 276, 1872-1874. doi: 10.1126/science.276.5320.1872

Conflict of Interest Statement: The authors declare that the research was conducted in the absence of any commercial or financial relationships that could be construed as a potential conflict of interest.

Copyright $\odot 2016$ Pandey, Sharma and Pandey. This is an open-access article distributed under the terms of the Creative Commons Attribution License (CC BY). The use, distribution or reproduction in other forums is permitted, provided the original author(s) or licensor are credited and that the original publication in this journal is cited, in accordance with accepted academic practice. No use, distribution or reproduction is permitted which does not comply with these terms. 